\title{
Sustainability Based on Risk Management of Batik Sasirangan SMEs in the Banjarmasin City
}

\author{
Sufi Jikrillah ${ }^{1}$, Muhammad Ziyad ${ }^{2}$, Doni Stiadi ${ }^{3}$, Asrid Juniar ${ }^{4, *}$ \\ ${ }^{123}$ Student of Management Science Doctoral Program, University of Jember, Jember, Indonesia \\ ${ }^{1234}$ Lecturer of Economics and Business Faculty, Lambung Mangkurat University, Banjarmasin, Indonesia \\ *Corresponding author.Email: asridjuniar@ulm.ac.id
}

\begin{abstract}
This study aims to analyze risk management as a basis for measuring the sustainability of the Sasirangan batik SMEs in the Banjarmasin City. The number of respondents studied were 39 entrepreneurs using questionnaires and in-depth interviews to dig up information in order to obtain an overview of the strengths, weaknesses, opportunities and challenges faced by the company. The data analysis technique uses SWOT analysis and risk management processes based on ISO 31000 in 2018. The results show that capital risk, human resource risk and raw material risk must be a concern in order to ensure the sustainability of the Sasirangan batik SME business in Banjarmasin City. The owner of the Sasirangan batik SMEs is the determining factor as an internal risk controller through increasing the ability and knowledge of risk management.
\end{abstract}

Keywords: Risk management, SMEs, SWOT analysis.

\section{INTRODUCTION}

Risk will always be encountered in the business world because of the unpredictable uncertainty about deviations from the desired expectations. Uncertainty is a source of ineffectiveness and an obstacle for all organizations [1], [2]. Likewise, with SMEs which are businesses with limited capital and knowledge which can be a business failure that leads to bankruptcy. For SMEs, efficient operations and effective management strategies are the keys to success in reducing uncertainty, improving performance and competitiveness [1], [2]. Sources of uncertainty for SMEs are demand, technology and competition. This source of uncertainty has an impact on performance [3]. The emergence of the COVID-19 pandemic has become one of the disruptions for most economic activities in the world. SMEs are among those affected by the measures implemented to prevent the spread of the virus so that uncertainty arises [4].

Companies need to strengthen the flow of liquidity, human resources and digital competencies to deal with uncertainty [4]. Resource utilization in an environment of uncertainty is related to RBV theory [5]. Generally, SMEs depend on buyers, supplies, employees and resource providers [6]. Another factor related to uncertainty that has an impact on the performance of
SMEs is the network, especially those related to exports [7]. Identifying the impact of environmental uncertainty on business, especially in developing countries and determining the differences between micro, small and medium enterprises is important for the government [8]. Innovation is also an important factor in dealing with uncertainty, especially due to the complexity of changes in external forces [9].

Risk management is the most important issue for every organization, the process of identifying business risks and financial risks is the strategic focus of the organization [10]. For large companies, risk management has become a formal policy and has been structured so that it becomes an industry standard, while for SMEs that lack resources it is difficult to set standards even for their own businesses [11]. SMEs require the application of risk management strategies and methodologies, because they lack the resources to immediately respond to internal and external threats, leading to the potential for large losses that seriously threaten survival [12]. The results of research on risk management in SMEs indexed by the web of science and indexed by Scopus are 621 papers, this shows the breadth of literature studies on SME risk management [13]. The components of enterprise risk management (ERM) that SMEs need to pay attention to are risk 
appetite, environmental control, assessing the risk management framework and control activities [14].

The position of SMEs has an important and strategic role for the economy. The large number of SMEs is a force to absorb labor and the formation of gross domestic product. SMEs also have the advantage of being labor intensive and creating added value for other industries and complementing large industries (Sarfiah, 2019). In addition to playing a role in economic growth and employment, SMEs also play a role in distributing development results [15]. Small and medium enterprises (SMEs) play an important role in the Indonesian economy because they can spearhead the national industry, and absorb a lot of workers. In 2018, the number of SME business actors was 64.2 million units (99.99\%), SMEs contributed $60.3 \%$ of Indonesia's total gross domestic product (GDP). In addition, SMEs absorb $97 \%$ of the total workforce and $99 \%$ of the total employment.

One of the roles of SMEs (micro, small and medium enterprises) is to improve the welfare of the community [16]. SMEs are the key to economic development through new job opportunities and the production of goods or services [17], [18]. The economy in the 20th and 21 st centuries is different from the 19th century, the emergence of globalization emphasizes the role of SMEs as promoters of a healthy business climate and economic efficiency for developing countries. SMEs are profitable companies because they have the ability to adapt quickly, work with less capital but are more labor intensive and have low management costs [19]. SMEs are like engines for economic growth and eradicating poverty [20]. The new configuration of the world economy supports the expansion and expansion of the SMEs sector [21].

The form of local SMEs that has survived for a long time and is able to compete in local and global markets is the batik business. These businesses do not only rely on production with local content but have an important role in terms of access to resources and innovation [22]. Batik craft has even become the main livelihood for batik entrepreneurs for many years [23]. The trust factor is the foundation of a sustainable cooperative relationship for batik entrepreneurs [24]. Batik crafts are found in almost all regions in Indonesia and all have unique motifs according to the characteristics of each region in Indonesia. Batik crafts are even found in almost all Malay countries, including in several neighboring countries. One type of batik is Sasirangan originating from South Kalimantan Province. The growth and sustainability of the Sasirangan batik business in South Kalimantan
Province as one of the SMEs that are vulnerable due to uncertainty makes risk management important.

\subsection{Risk}

Risk is inherent in all aspects of business, the risk is not only the possibility of loss but also the possibility of profit. The risk is in accordance with the consequences of its realization in the business environment [10]. Risk is all human actions covering the business in every area of management and can be predicted based on experience by managing disturbances better [12], [25]. Business activities are faced with four types of risk, namely financial, hazard, operational and strategic risk [13].

Risk, by definition, is manifested in the reduced value of a business asset or forfeited business opportunity and stems from the functions performed within and within the environment of a business [11]. Risk is the possibility that an event, whether expected or not, could have an unfavorable effect on the organization. The company's risk is classified based on the impact it may have on different business operational activities [2].

SMEs do not have a standard of risk because the size of their operations rarely requires complete adherence to the same standards as the expectations of large companies. The most common risks experienced by SMEs are related to business risk, managerial risk, reputation risk, operational risk, moral risk, and legal risk. SMEs are more focused on recruiting workers who are able to handle their business directly [11].

\subsection{Risk Management}

Risk management is an important problem faced by every organization today. In general, risk management is the process of identifying risks, analyzing risks, assessing risks, managing and monitoring risks [10]. Risk management is tasked with identifying risks, assessing the probability of their occurrence, managing risks and then eliminating or reducing their impact with minimal investment of resources [12], [25]. The flow of risk management is divided into clinical risk management, disaster risk monitoring risks [10]. Risk management is tasked with identifying risks, assessing the probability of their occurrence, managing risks and then eliminating or reducing their impact with minimal investment of resources [12], [25]. The flow of risk management is divided into clinical risk management, disaster risk management, engineering risk management, enterprise risk management, financial risk management, insurance risk management, project risk 
management, strategic risk management and supply chain risk management [13].

Risk management describes the framework as a managed process for strategy formulation and the process of managing risk to realize company goals [14]. Risk management consists of eight related components, namely: internal environment, objective setting, event identification, risk assessment, risk response, control activities, information and communication, monitoring [12]. Risk management is an ongoing process which, if described, is presented in Figure 1 [26]:

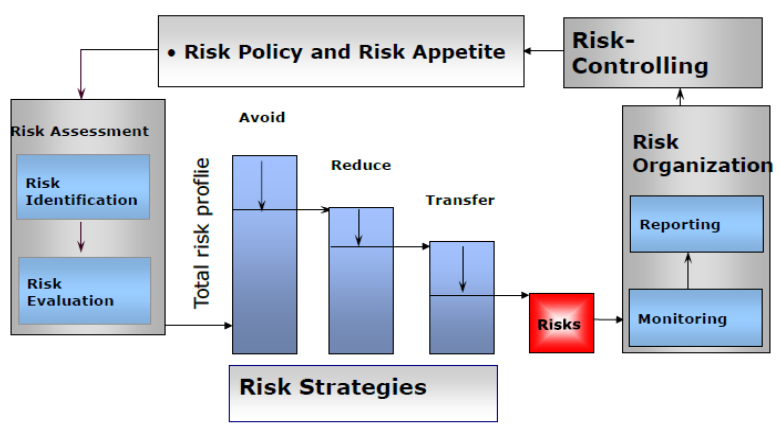

Figure 1. Risk Management Process.

Risk management is important to secure business capital, so risk management does not prohibit risk taking but what is important is to understand risk and involve risk in the development and growth of the company. The application of risk management contains continuous actions regarding awareness, identification, evaluation, development of risk management, decision making with methods according to the implications. The essence of risk management is the systematic flow of each step. Risk management in SMEs should not be an individual program but must be integrated with other management processes (business strategy planning, human resource management, financial management and customer relationship management) [2].

\subsection{The Role of SMEs}

The role of small and medium enterprises (SMEs) in the Indonesian economy can at least be seen from: (1) their position as a major player in economic activities in various sectors, (2) the largest provider of employment, (3) an important player in the development of business activities. local economy and community empowerment, (4) creating new markets and sources of innovation, and (5) contributing to maintaining the balance of payments through export activities [15]. There are four reasons that explain the strategic position of SMEs in Indonesia. First, SMEs do not require large capital as large companies so that the formation of this business is not as difficult as large businesses. Second, the required workforce does not require certain formal education. Third, most of them are located in rural areas and do not require infrastructure like large companies. Fourth, SMEs are proven to have strong resilience when Indonesia is hit by an economic crisis [27].

The contribution of SMEs in supporting the economy of a country so that the existence of SMEs is highly expected by any country because of its vital role in the development and progress of the economy to achieve public welfare. The establishment of a business in the SMEs sector is able to absorb the number of workers who are ready to work but have not got a job so that it can reduce the number of unemployed. The development of growth in the micro business sector will open up more job opportunities and in turn will increase people's income [16], [18]. The contribution of SMEs can be summarized in several important points, as follows: a) solving the country's employment problems. b) make a significant contribution to GDP - country. c) make a valuable contribution to the development of the company's large business. d) also contributes significantly to the country's exports and imports [17].

The main actor of national development in many countries is SMEs, many studies show the importance of SMEs for the economy of a country. Several programs and policies to support and enhance innovation and entrepreneurship are implemented by governments in many countries in the world [19]. SMEs globally have contributed to the availability of goods and services for the community, without SMEs large companies may not be able to optimally meet the demand for goods and services [20]. SMEs become a balancer in micro and macro economies as well as counterbalance monopolies and oligopolies and become a counterweight to large companies in market control [21].

\section{METHODOLOGY}

The object of this research is the Sasirangan batik SMEs located in Banjarmasin City which are registered and meet the administrative requirements of the Banjarmasin City Industry and Trade Office and total 39 businesses. The sampling method used saturated sampling, that is, all members of the population become members of the sample. The data collection method used a survey by distributing questionnaires and conducting in-depth interviews. The data analysis technique in this study uses a risk management process based on ISO 31000 in 2018 . The 
stages of analysis in this study is shown in Figure 2 below.

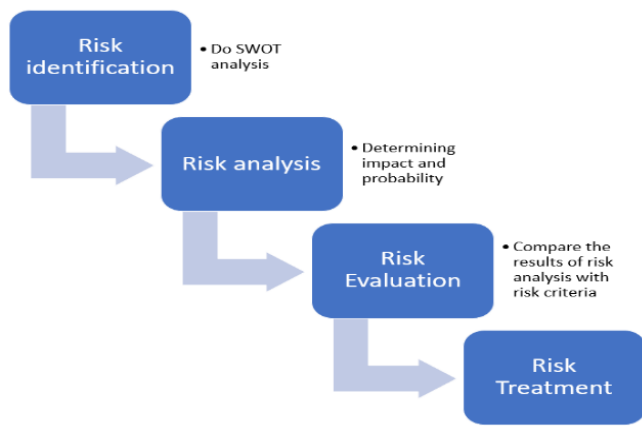

Figure 2. Analysis Stage.

\section{RESULTS AND DISCUSSION}

The first stage in data analysis is to identify risks through a SWOT analysis so that it is known the strengths, weaknesses, opportunities and threats faced by the Sasirangan batik SMEs in Banjarmasin City. An important factor in SWOT analysis is extracting information related to internal and external factors [28], [29] : 1) internal factors that affect the formation of Strength and Weakness ( $\mathrm{S}$ and $\mathrm{W}$ ). This factor is related to the conditions that occur in SMEs; 2) external factors that affect the formation of Opportunities and Threats $(\mathrm{O}$ and $\mathrm{P})$. This factor is related to conditions that occur outside of SMEs. Table 1 shows the results of the recapitulation of extracting the SWOT component from the Sasirangan batik SMEs in Banjarmasin City.

Based on the results of the SWOT analysis, the identified risks in Sasirangan batik SMEs are as follows (Table 2): capital risk (lack of capital and not
Table 1. Strengths, Weaknesses, Opportunities and Threats to SMEs in Sasirangan batik in Banjarmasin City.

\begin{tabular}{|c|c|}
\hline Strengths & Weaknesses \\
\hline 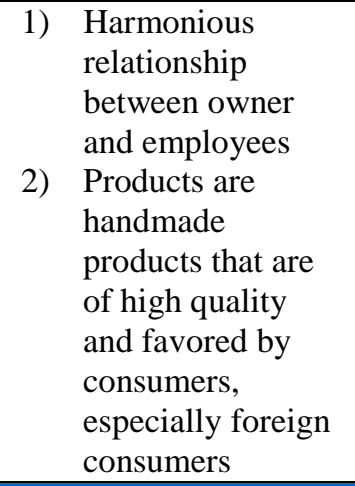 & $\begin{array}{l}\text { 1) The price of raw } \\
\text { materials is getting } \\
\text { more expensive } \\
\text { 2) Limited funding } \\
\text { because only } \\
\text { partially received } \\
\text { assistance from the } \\
\text { local } \\
\text { government/bank } \\
\text { 3) Financial } \\
\text { management that is } \\
\text { still conventional }\end{array}$ \\
\hline Opportunities & Threats \\
\hline $\begin{array}{l}\text { 1) Many government } \\
\text { programs to assist } \\
\text { SMEs activities } \\
\text { 2) The existence of } \\
\text { people's business } \\
\text { credit facilities for } \\
\text { all business fields }\end{array}$ & 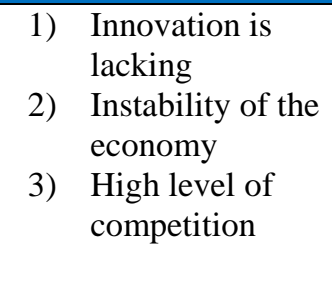 \\
\hline
\end{tabular}

touched by government assistance); human resource risk (financial management is still not efficient, have not utilized training from related parties); raw material risk (the price of raw materials is getting more expensive); operational risk (lack of innovation); equipment risk (technology is still simple).

The second stage is to make an analysis with a risk matrix based on the results of risk identification. Risk analysis matrix $5 \times 5$ is then developed. The risk matrix

Table 2. Treatment of Risk

\begin{tabular}{|c|c|c|c|c|}
\hline Risk & $\begin{array}{c}\text { Risk } \\
\text { Level/Zone }\end{array}$ & Solution & How & Who \\
\hline Capital & $\begin{array}{l}\text { Very high } \\
\text { (red) }\end{array}$ & $\begin{array}{l}\text { Get a loan or assistance from } \\
\text { the local government/bank }\end{array}$ & $\begin{array}{l}\text { Good financial } \\
\text { records/administration (bankable) }\end{array}$ & $\begin{array}{l}\text { Owners and } \\
\text { employees }\end{array}$ \\
\hline HR & $\begin{array}{l}\text { Very high } \\
\text { (red) }\end{array}$ & Attend training/ workshops & $\begin{array}{l}\text { Owners and employees are always } \\
\text { actively involved in the SMEs } \\
\text { community so that they always get } \\
\text { information about SMEs training }\end{array}$ & $\begin{array}{l}\text { Owners and } \\
\text { employees }\end{array}$ \\
\hline $\begin{array}{l}\text { Raw } \\
\text { material }\end{array}$ & Height (red) & $\begin{array}{l}\text { - Do resizing } \\
\text { - Raw material stock }\end{array}$ & Has a special place for raw materials & Owner \\
\hline $\begin{array}{l}\text { Operational } \\
\text { process }\end{array}$ & $\begin{array}{l}\text { Medium } \\
\text { (yellow) }\end{array}$ & Creating a network & $\begin{array}{l}\text { Expanding coverage/area to get raw } \\
\text { material supply }\end{array}$ & Owner \\
\hline $\begin{array}{l}\text { Equipment } \\
\text { machine }\end{array}$ & $\begin{array}{l}\text { Low (light } \\
\text { green) }\end{array}$ & $\begin{array}{l}\text { Using new } \\
\text { equipment/machines and the } \\
\text { use of the latest technology }\end{array}$ & $\begin{array}{l}\text { Purchase the latest } \\
\text { machines/equipment by using } \\
\text { capital assistance from the } \\
\text { government and capital loans from } \\
\text { banks }\end{array}$ & Owner \\
\hline
\end{tabular}


for Sasirangan batik SMEs is presented in Figure 3 below.

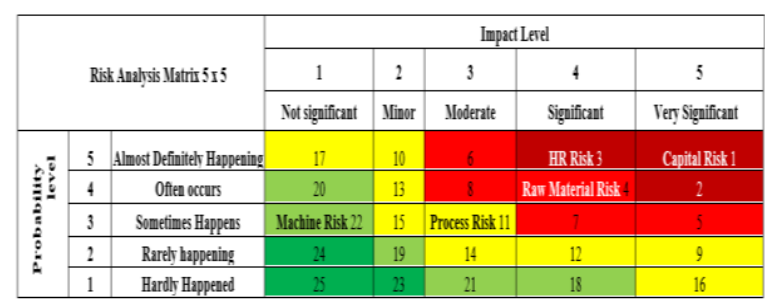

Figure 3 Sasirangan Batik SMEs Risk Matrix.

The third stage is based on the risk matrix, a risk evaluation is carried out. There are three risks included in red, namely capital risk, human resource risk and raw material risk. The red color (unacceptable) means that risk treatment must be carried out immediately even though the cost is expensive because it involves the continuity of the company so that capital risk, human resource risk and raw material risk become the main focus because these risks have a major impact on SMEs in Sasirangan batik in Banjarmasin City. One risk is included in the yellow color category (issue), namely operational risk, meaning that risk treatment needs to be carried out so that the risk is minimized. One risk is included in the green color category (supplementary issue), namely machine risk, meaning that risk treatment is based on cost benefit analysis.

The last stage is risk treatment, based on the root of the problem obtained from the SWOT analysis and risk identification, then risk mitigation is carried out to reduce its impact with the contingency plan method to find solutions. The following table 2 presents the results of the treatment of the risks faced by the Sasirangan batik SMEs in the Banjarmasin City.

Based on the results of the study, it was shown the importance of digging up information related to the strengths, weaknesses, opportunities and threats faced by the Sasirangan batik SMEs in the Banjarmasin City so that a risk mapping could be carried out [28]-[30] on the use of SWOT analysis to determine the company's strategic direction. The role of batik owners/entrepreneurs in increasing product innovation and marketing innovation is an important factor of batik business efficiency so that it can reduce risks that may arise and the results of this study are in line with research results [22]. Quadruple helix synergy is very important for the progress of Sasirangan batik SMEs in Banjarmasin City, this recommendation is in line with research results [28]. Local governments are expected to be able to provide support for the success of batik MSME programs that were initiated independently and collectively [23]. The orientation of innovation, customers, suppliers, networks and absorption capacity play a role in reducing the risks that arise in the Sasirangan batik SMEs so as to lead to business sustainability, these results are in line with research results [31].

Risk management with risk identification can classify for decision making for SMEs [2], [10]. Capital risk, human resource risk and raw material risk are a concern for SMEs batik Sasirangan in Banjarmasin City, these results prove the results of five studies, 2018 that research on SMEs risk now appears new risk management related to project risk management, strategic risk management and management supply chain risk. SMEs batik sasirangan need to build simple internal control through owners for the supervisory function, these results are in line with research results [11], [12], [14] which show risk management is important for SMEs to reduce exposure to business loss.

\section{CONCLUSION}

The results showed that the Sasirangan batik SMEs in Banjarmasin City based on risk management analysis were faced with capital risk, human resource risk and raw material risk which were the main concerns to ensure business sustainability. The owner of the Sasirangan batik SMEs is the determining factor as an internal risk controller through increasing the ability and knowledge of risk management.

\section{REFERENCES}

[1] B. M. Sopha, F. Jie, and M. Himadhani, "Analysis of the uncertainty sources and SMEs' performance," J. Small Bus. Entrep., vol. 33, no. 1, pp. 1-27, 2021, doi: 10.1080/08276331.2020.1764737.

[2] L. Duong, "Effective Risk Management Strategies for Small-Medium Enterprises and Micro Companies," 2009.

[3] T. A. Chin, A. B. A. Hamid, A. Rasli, and H. H. Tat, "A Literature Analysis on the Relationship between External Integration, Environmental Uncertainty and Firm Performance in Malaysian SMEs," Procedia - Soc. Behav. Sci., vol. 130, pp. 75-84, 2014, doi: 10.1016/j.sbspro.2014.04.010.

[4] M. Rodrigues, M. Franco, N. Sousa, and R. Silva, "Covid 19 and the business management crisis: An empirical study in smes," Sustain., vol. 13, no. 11,2021 , doi: 10.3390/su13115912.

[5] Y. Temouri, K. Shen, V. Pereira, and X. Xie, "How do emerging market SMEs utilize resources in the face of environmental 
uncertainty?," BRQ Bus. Res. Q., vol. 23, 2020, doi: 10.1177/2340944420929706.

[6] H. Etemad, "Managing uncertain consequences of a global crisis: SMEs encountering adversities, losses, and new opportunities," J. Int. Entrep., vol. 18, no. 2, pp. 125-144, 2020, doi: 10.1007/s10843-020-00279-z.

[7] E. Babakus, U. Yavas, and A. Haahti, "Perceived uncertainty, networking and export performance: A study of Nordic SMEs Emin Babakus Ugur Yavas Antti Haahti Article," Eur. Bus. Rev., vol. 18, no. 1, pp. 4-13, 2006.

[8] A. Padukkage, V. Hooper, and J. Toland, "Implications of environmental uncertainty for business-IT alignment: A comparative study of SMEs and large organizations," in ACIS 2015 Proceedings - 26th Australasian Conference on Information Systems, 2015.

[9] C. Uzkurt, R. Kumar, H. S. Kimzan, and H. Sert, "The impact of environmental uncertainty dimensions on organisational innovativeness: An empirical study on SMEs," Int. J. Innov. Manag., vol. 16, no. 2, 2012, doi: 10.1142/S1363919611003647.

[10] F. S. Zoghi, "Risk Management Practices and SMEs: An empirical study on Turkish SMEs," Int. J. Trade, Econ. Financ., vol. 8, no. 2, pp. 123-127, 2017, doi: 10.18178/ijtef.2017.8.2.550.

[11] N. A. Krüger and N. Meyer, "The Development of a Small and Medium-Sized Business Risk Management Intervention Tool," J. Risk Financ. Manag., vol. 14, no. 7, p. 310, 2021, doi: $10.3390 /$ jrfm14070310.

[12] N. Ekwere, "Framework of Effective Risk Management in Small and Medium Enterprises (SMESs): a Literature Review," Bina Ekon., vol. 20, no. 1, pp. 23-46, 2016, doi: 10.26593/be.v20i1.1894.23-46.

[13] P. F. de A. Lima, M. Crema, and C. Verbano, "Risk management in SMEs: A systematic literature review and future directions," Eur. Manag. J., vol. 38, no. 1, pp. 78-94, 2020, doi: 10.1016/j.emj.2019.06.005.

[14] H. K. Y. Angeline and Y. S. Teng, "Enterprise Risk Management: Evidence From SmallMedium Enterprises," Malaysian Account. Rev., vol. 15, no. 2, pp. 151-170, 2016.

[15] A. H. Putra, "Peran Umkm Dalam Pembangunan Dan Kesejahteraan Masyarakat Kabupaten Blora," J. Anal. Sosiol., vol. 5, no. 2, 2016, doi: 10.20961/jas.v5i2.18162.
[16] K. N. Srijani, "Peran UMKM (Usaha Mikro Kecil Menengah) Dalam Meningkatkan Kesejahteraan Masyarakat," Equilib. J. Ilm. Ekon. dan Pembelajarannya, vol. 8, no. 2, p. 191, 2020, doi: 10.25273/equilibrium.v8i2.7118.

[17] D. Morina and P. Gashi, "The Role of SMEs on the Economic Development: Kosova's Case," CRC-Journal Vol., vol. 3, no. 5, 2016, doi: 10.2139/ssrn.2820980.

[18] H. Karadag, "The Role of SMEs and Entrepreneurship on Economic Growth in Emerging Economies within the Post-Crisis Era: an Analysis from Turkey," J. Small Bus. Entrep. Dev., vol. 4, no. 1, pp. 22-31, 2016, doi: 10.15640/jsbed.v4n1a3.

[19] H. Keskin, C. Sentürk, O. Sungur, and H. M. Kiris, "The importance of SMEs in developing economies," in 2nd International Symposium on Sustainable Development, 2010, pp. 183-192.

[20] N. T. Katua, "The Role of SMEs in Employment Creation and Economic Growth in Selected Countries," Int. J. Educ. Res., vol. 2, no. 12, pp. 461-472, 2014.

[21] L. I. Savlovschi and N. R. Robu, "The Role of SMEs in Modern Economy," Econ. Ser. Manag., vol. 14, no. 1, 2011, doi: 10.1242/jcs.101.1.35.

[22] E. D. Kurniati and S. D. W. Prajanti, "Batik SMEs Efficiency and Entrepreneurship Role in Innovation," Jejak, vol. 11, no. 2, pp. 375-389, 2018, doi: 10.15294/jejak.v11i2.16058.

[23] O. A. W. Riyanto, S. Riyadi, and M. I. Kusuma, "Small-Medium Enterprises (SMEs) Batik Tulis in Jetis Village, District of Sidoarjo," Kontribusia (Research Dissem. Community Dev., vol. 1, no. 2, p. 29, 2018, doi: 10.30587/kontribusia.v1i2.624.

[24] F. Naili, A. Naryoso, and E. Ardyan, "Model of relationship marketing partnerships between batik SMEs and batik distributors in central Java, Indonesia," Int. J. Soc. Ecol. Sustain. Dev., vol. 8, no. 4, pp. 1-14, 2017, doi: 10.4018/IJSESD.2017100101.

[25] C. Verbano and K. Venturini, "Managing risks in SMEs: A literature review and research agenda," J. Technol. Manag. Innov., vol. 8, no. 3, pp. 186197, 2013, doi: 10.4067/s071827242013000400017.

[26] T. Henschel, "Risk Management in SMEs," 2016.

[27] S. Sarfiah, H. Atmaja, and D. Verawati, "UMKM Sebagai Pilar Membangun Ekonomi Bangsa," J. 
REP (Riset Ekon. Pembangunan), vol. 4, no. 2, pp. 1-189, 2019, doi: 10.31002/rep.v4i2.1952.

[28] A. Juniar and R. Rahmawati, "Synergy of Quadruple Helix in The Development of Small Industries Processing Fisheries in Banjar District," Int. J. Sci. Dev. Res., vol. 3, no. 11, pp. 392-399, 2018.

[29] A. Juniar and I. Fadah, "Efficient financial management strategy for indonesian health BPJS," Int. J. Sci. Technol. Res., vol. 8, no. 07, pp. 403-407, 2019.

[30] M. T. Nawawi, Z. Wiryawan, and R. Rodhiah, "Management Implementation of Batik Sme Strategy in Jambi," J. Bus. Soc. Rev. Emerg. Econ., vol. 5, no. 2, pp. 379-388, 2020, doi: 10.26710/jbsee.v5i2.816.

[31] N. C. Nawi, A. Al Mamun, R. R. R. Daud, and N. A. M. Nasir, "Strategic orientations and absorptive capacity on economic and environmental sustainability: A study among the batik small and medium enterprises in Malaysia," Sustain., vol. 12, no. 21, pp. 1-16, 2020, doi: 10.3390/su12218957. 